\title{
NON-STATE ACTOR IN CONFLICT TRANSFORMATION: MULTICULTURALEDUCATION OF MA DAARUL ULUUM PUI MAJALENGKA TOWARDS ETHNO-RELIGION CONFLICT IN SOUTHERN THAILAND
}

\author{
Zabieb Nu'aim Ridwan ${ }^{1} \&$ Sugito ${ }^{2}$ \\ ${ }^{1}$ Departement of International Relations, Universitas Muhammadiyah Yogyakarta \\ ${ }^{2}$ Departement of International Relations, Universitas Muhammadiyah Yogyakarta
}

Corresponding Author: Zabieb Nu'aim Ridwan, E-mail: zabieb.nr@gmail.com

\begin{tabular}{l}
\hline ARTICLE INFO \\
\hline Received: $25-06-2021$ \\
Accepted: $25-10-2021$ \\
Published: $30-10-2021$ \\
Volume: 4 \\
Issue: 2 \\
DOI: \\
https://doi.org/10.33019/berumpun.v3i1.55 \\
\hline KEYWORDS \\
\hline
\end{tabular}

Non-state Actor; Peace education; Conflict Transformation; Ethno-religion; Conflict; Southern Thailand.

\section{ABSTRACT}

The conflict between the Malay Muslim and the Thailand government in Southern Thailand has become one of the ethno-religion conflicts that effects the security of the Southeast Asian region. Various actors, both local and international, have attempted to broker peace between the parties in the conflict. Based on the conflict transformation theory, this study aims to discover the role of MA Daarul Uluum PUI Majalengka as a non-state actor in promoting peace through efforts of conflict transformation in the Southern Thailand ethno-religion conflict. The research method used is qualitative type research with descriptive analysis technique, through primary and secondary type data management. Primary data was obtained from interview and secondary data was obtained from written sources that support the study. This research shows there is an effort made by MA Daarul Uluum PUI Majalengka to conduct peace education through a student and teacher exchange scheme with several schools in Thailand that have Buddhist identity backgrounds in order to grow tolerance between ethnicities and religions in Thailand.

\section{INTRODUCTION}

Along with the development of international activities, various concepts and ideas in supporting the creation of an ideal of world peace have been carried out, one of which is by supporting efforts to recognize and fulfill basic human rights as declared in the Universal Declaration of Human Rights (Kymlicka, 2003). These values become a set of aspects that underlie efforts to create justice, independence, and the ideals of world peace. On the other hand, this spirit of peace is also brought by the Association of Southeast Asian Nations (ASEAN) as an organization that accommodates countries in Southeast Asia. One of ASEAN's 
missions is to be able to build cultural development as well as efforts for regional stability and peace as well as respect for the principles of the United Nations (Liwe, 2018).

As an organization of countries in Southeast Asia that is rich in culture, ASEAN needs to apply the concept of multiculturalism that brings values of peace. According to (Syafe'i et al., 2001) multiculturalism is a concept where a community in the context of nationality can recognize diversity, differences and cultural plurality, be it race, ethnicity, gender and religion. A concept that provides an understanding of pluralistic nation that is filled with diverse or multicultural cultures to maintains equality and respect for human rights, justice, law, and politic. Thus, a multicultural nation is a nation whose ethnic or cultural groups can coexist peacefully with respect for other cultures.

However, the implementation of multiculturalism values today still faces various challenges such as conflict that motivated by differences in identity (Kristimanta, 2020). Several conflicts concerning identity differences are still ongoing in the Southeast Asia region. Countries in the Southeast Asia region have long experienced conflicts that are motivated by identity problems. Starting from the communal conflict in Rakhine, Myanmar (Raharjo, 2015), ethno-nationalist sentiment-based conflict in the Philippines (Sobandi, 2011), to conflicts that arose due to cultural assimilation policies towards the Muslim community in Thailand (Kusuma, 2017), whose sustainability indirectly shows that the implementation of multiculturalism values in the Southeast Asian region is still hindered by several challenges.

The occurrence of these conflicts or problems is not only a matter of urgency for the country concerned, but it must also come into the attention of the international community, especially in conflict between ethnics or religion in the Southeast Asia region, where the situation has quite an impact on the stability of the region and surrounding area (Fathurachmi, 2014), regarding political, economic, as well as security stability (Rinayuhani, 2014). Such as the case of Thailand's role in the conflict that happened between the Rakhine Buddhist ethnic and Rohingya ethnic minority, there was a wave of Rohingya refugees from Myanmar towards neighboring countries, one of them being Thailand, who helped provide 
humanitarian assistance (Ludfiani et al., 2017). Despite thus, Thailand itself has historically had a prolonged domestic conflict triggered by differences in identity.

From a historical perspective, the conflict in Southern Thailand is an identity conflict between the Buddhist majority supported by the Thai government, and the Muslim community as a minority living in the Southern Thailand region (Ekawati, 2019), such as the provinces of Pattani, Yala and Narathiwat plus parts of the provinces of Satun and Songkhla, which are directly adjacent to Malaysia where the population consists of ethnic Malays (Wayeekao, 2016). As of 2020, the Thai Muslim community is a minority with a population of $4.6 \%$ of the total Thai population (United Nations, Department of Economic and Social Affairs, 2020).

During the leadership of King Plaek Phibulsongkhram in 1938-1944 and 1947-1957, there was an implementation of policies related to the values of nationalism (Mahmud, 2004), in which there was an attempt to assimilate the Thai language and culture throughout Thailand, including in the southern region, leading to resistance from the Malay-speaking Muslim Malay community. Furthermore, this was added by the disputes of identity politics, as the government started to emphasize Buddhism as the national religion. The policy triggers a wave of prolonged conflict which includes 3 phases, these phases are as follow:

Table 1. Phases of the conflict of identity differences in the southern Thailand region

\begin{tabular}{|c|c|c|c|}
\hline PHASE & YEAR & CAUSE & CASE \\
\hline $\begin{array}{c}\text { PHASE } \\
1\end{array}$ & $\begin{array}{c}1960- \\
1998\end{array}$ & $\begin{array}{l}\text { The assimilation policy carried out by the } \\
\text { Thai government gave birth to groups of } \\
\text { resistance movements for the independence } \\
\text { of Southern Thailand. }\end{array}$ & $\begin{array}{l}\text { Resistance carried out by various } \\
\text { groups of the independence } \\
\text { movement such as BNPP, BRN and } \\
\text { PULO. }\end{array}$ \\
\hline $\begin{array}{c}\text { PHASE } \\
2\end{array}$ & $\begin{array}{l}2001- \\
2004\end{array}$ & $\begin{array}{l}\text { The ineffective implementation of Thailand's } \\
\text { central government policies in dealing with } \\
\text { social problems in Southern Thailand, } \\
\text { especially in terms of the inclusiveness of the } \\
\text { Thai Muslim community. }\end{array}$ & $\begin{array}{l}\text { The intensity of the conflictincreased } \\
\text { with the insurgency activity which } \\
\text { further exacerbated the situation, } \\
\text { with a lot of bloodshed through } \\
\text { coordinated armed attacks. }\end{array}$ \\
\hline
\end{tabular}


BERUMPUIN

International Journal of Social, Politics, and Humanities

https://berumpun.ubb.ac.id/index.php/BRP

\begin{tabular}{lrl}
\hline PHASE & $\begin{array}{l}\text { Efforts to resolve the conflict are still faced } \\
\text { with several challenges to be accepted by the }\end{array}$ \\
3 & Present & $\begin{array}{l}\text { conflicting parties in the process of peace } \\
\text { efforts. }\end{array}$
\end{tabular}

The spread of the southern Thai independence movement groups, with the emergence of various new independence movements such as the RKK (Runda Small Group).

Source: (Nuereng, 2016)

The conflicts that occurred between the Thai government and the Muslim community in Southern Thailand were accumulated into three phases. The first phase occurred in 1960-1998, in which the regulation of cultural assimilation policies eventually triggered a conflict which was colored by the emergence of various resistance movements for the independence of southern Thailand such as the BNPP (Barisan Nasional Liberation Patani), BRN (Barisan Revolution National) and PULO (Patani United Liberation Organization). Along with the dynamics of the conflict in this first phase, several southern Thai resistance movements made an alliance to unite and carry out military operations together. The second phase occurred in 2001-2004 which showed an increase in the intensity of the conflict with several rebellions that resulted in quite a number of victims. Being in the third phase, which began in the year 2005 until today, the conflict is faced with several efforts to resolve it, behind various dynamics situation that are considered increasingly complex.

The ongoing conflict which gradually continued until 2005 turned out to give more attention to international actors to help resolve the conflict, one of which is the OIC (Islamic Cooperation Organization) as an international organization that is engaged in a unified network of Islamic countries cooperation with go directly to the field to resolve the conflict, starting with gathering facts about how the conflict occurred (Ashayagachat, 2016). The OIC took the initiative to invite other countries that have good relations with Thailand to help resolve the conflict. In this case, Malaysia which was appointed as a mediator and facilitator in negotiating the conflict. However, assistance from Malaysia as a mediator in the process of mediating the conflict situations did not succeed as a whole due to the distrust of the parties involved in several peace process efforts (Maharani, 2018). 
Efforts to resolve a conflict by a third party do not always have to be done through formal means that can only be played by state actors. The role of non-state actors as third parties also has the potential to play an important role as promoters in resolving conflicts in a country. As one of the non-state actors, MA Daarul uluum PUI Majalengka takes an active role in promoting peace through the education sector in the form of teacher and student exchange. Established as a private Islamic school in Indonesia, MA Daarul Uluum PUI Majalengka through this program seeks to promote the values of multiculturalism based on religious identity between Muslim and Buddhist groups.

Therefore, this study aims to describe and analyze the role of MA Daarul uluum PUI Majalengka in promoting peace through strategies and its role in the multiculturalism education sector to be actively involved in building peace efforts through non-formal ways as an alternative step of conflict transformation efforts in southern Thailand region. This study will also complement the study of the role of non-state actors in identity conflicts in contemporary international relations studies.

\section{LITERATURE REVIEW}

Studies on peace efforts or conflict resolution in Southern Thailand have been widely discussed by scholars in international relations. Efforts to resolve the conflict using formal channels through the role of state actors continue to be carried out as described by (Sharqieh, 2012), if the OIC utilizes its diplomatic influence to get involved in the peace process by observing and providing recommendations as well as steps to mediate conflicts that occur. Additionally, the involvement of Malaysia as a neighboring country recommended by the OIC to become a mediator and facilitator in dealing with diplomatic tensions in Thailand, was recorded from 2005 to 2007 in the study (Alunaza SD \& Amijoyo, 2019). Meanwhile, as explained by (Zahidi, 2015), Indonesia's involvement as one of the largest Islamic countries with the influence of its foreign policy in the Southeast Asia region is one of its own strengths in efforts to resolve the southern Thailand conflict, if Indonesia takes the initiative to play an active role as a mediator in the southern Thailand conflict.

Peace efforts in the southern Thailand conflict through the role of non-state actors have also been widely discussed along with the development of international relations, as 
described in the research by (Margono, 2015). This is due to the increasing potential role of non-state actors in international relations activities. In the research by (Sholeh, 2017), it is elaborated that Indonesian Muslim communities such as Hasyim Muzadi and several NU figures "Nahdatul Ulama" as Indonesian Muslim community organizations, play a role in peace efforts through traditional Muslim approaches and Malay traditions, in which Hasyim Muzadi and several NU figures carry out active communication with leaders of Islamic boarding schools and Islamic schools in turbulent conflict areas, as a form of mediation and peace between Muslims in Southern Thailand and the Thai government. In addition, as one of the largest Islamic civil society organizations in Indonesia, Muhammadiyah also plays its diplomatic role by establishing communication with the Thai government and Muslim community organizations in southern Thailand in mediating the ongoing conflict (Latief \& Nashir, 2020). In addition to establishing communication between the two conflicting parties, Muhammadiyah also plays a role through its education sector by opening up opportunities for students in southern Thailand to be able to study at various Indonesian Muhammadiyah universities.

The researcher aims to examine the issue through an approach different from the previous studies. There are several similarities in previous researches, such as: 1) the majority of previous studies have emphasized the role of state actors in promoting a country's peace efforts, meaning that formal approaches are more often used in these efforts. 2) Although there are also studies that discuss the role of non-state actors, previous studies have emphasized the role of non-state actors as facilitators in conflict resolution efforts, by establishing communication with both parties in the conflict, and contributing to their role in providing formal education facilities. Therefore, the researcher will focus more on the use of a multiculturalism approach through the education sector, in order to fill in the gaps of previous similar research. 3) In addition, the majority of research on the role of state and non-state actors uses a direct approach to conflict parties, while this study will explain the role of non-state actors in promoting the values of multiculturalism to the environment outside the conflict area to participate and diminish various negative stigmatizations in the community around Thailand. 
This study was conducted by referring to the concept of conflict transformation as mentioned in several studies such as (Lederach, 1997) and (Miall, 2004) regarding conflict management. Conflict transformation is a concept in the efforts to face conflict through the process of conflict management with holistic and multi-faceted means, or it can also be defined as comprehensive conflict management using several approaches. In its implementation, the concept of conflict transformation involves transforming relations, interest, debates, or a set of rules able to sustain the continuity of conflict and implicates that there is a change in relations, social structure, as well as circumstances that in the end will trigger or generate conflict. In this case, the main goal of conflict transformation is to resolve the wider sources of conflict by changing the negative force of conflict into a more positive social force in order to reach and realize long term peace.

The book (Lederach, 2003) states that there are four aspects that are necessary to be transform in the efforts of conflict transformation which are as follows:

\subsection{Personal transformation}

Personal transformation refers to the effort of transformation at an individual's level. This change concerns several aspects such as cognitive, emotion, perception, and spiritual aspects with an aim to free the individual from the destructive effects of social conflicts that includes physical and mental wounds.

\subsection{Relational transformation}

Relational transformation refers to the efforts of transforming communication and interaction patterns that are influenced by conflict in order to build a communication link that is more oriented in building mutual understanding.

\subsection{Structural transformation}

Structural transformation refers to the fulfillment of basic rights on the basis of society needs through means of managing social, economic, political, and institutional relations.

\subsection{Cultural transformation}

Cultural transformation refers to efforts of constructive conflict control towards cultural patterns that generate conflict. 
In conducting conflict transformation, all four aspects mentioned above are interrelated to one another. In this study, the researcher will conduct a deeper analysis of MA Daarul Uluum PUI Majalengka's strategy of conflict transformation that describes all four aspects above. (Lederach, 1997) and (Dudouet, 2006) have mapped the types of actors and their roles in conflict transformation. Among them are states and inter-governmental organization, humanitarian and development organizations, and international nongovernmental organizations that address conflict prevention and transformation. The role of a non-state institution is vital as an agent of peace since non-state institutions are able to substitute the role of a state who fails to perform their function as well as collaborate with state actors when they have a similar goal (Sugito et al., 2020). In the context of this study, the researcher will focus on the role of MA Daarul Uluum PUI Majalengka as one of the Islamic schools in Indonesia that collaborates with schools in Thailand in their effort to conduct conflict transformation as a development organization that moves in developing human resources through education.

In the application of conflict transformation as a means of building peace, education plays a very central role. The United Nations Children's Fund (UNICEF) affirms that education is one of the media of peacebuilding in the way that its role is to promote knowledge, skills, and values of behavior that enables society to prevent conflict and violence, solve conflict through peaceful means, as well as create a conducive condition with the spirit of peace values (Fountain, 1999). Due to this, the concept of peace education theory explains how education can play an important role in building peace, one of which through implementing conflict transformation.

According to (Harris, 2007), peace education theory is divided into several types, wherein an approach using peace education aids the researcher in describing the role of MA Daarul Uluum PUI Majalengka in minimalizing an identity based conflict case in Thailand. There are five types of peace education: international education, human rights education, development education, environmental education and conflict resolution education. Out of the five types, the researcher utilizes two types that has been deemed to be suitable to the 
focus of this study. Those two types are human rights education and conflict resolution education.

Human rights education focuses on resolving conflicts such as civil violence, domestic, cultural and ethnical conflict, where the process of resolving the matter aims to respect human values that encompasses accepting different identity backgrounds, as well as building mutual care towards people with different social community backgrounds. Meanwhile, conflict resolution education leans in the direction of building peacemaking skills such as conflict resolution through skills of relation with other people. For example, anger management, self-control, emotional awareness, developing empathy, assertiveness, and problem solving to manage conflict within oneself, as well as not excluding the possibility of other violent acts such as civil, cultural, environmental, and even global violence.

The role of MA Daarul Uluum PUI Majalengka in promoting peace within the Southern Thailand identity conflict is carried out through nonviolence approaches. In this case, the methods are similar to the theory of (Galtung, 1996) regarding the concept of positive peace, where one can use non-coercive methods in order to prevent a conflict from arising. The existence of a form of conflict resolution that is non-coercive and democratic in nature will create social justice, economic prosperity, and wide political division that is the preliminary steps to building positive peace. Thus, structural violence, such as racism and religious intolerance will no longer happen.

\section{METHODOLOGY}

This study used qualitative research method with a descriptive analysis technique. The aim of qualitative research itself is to describe a situation/phenomenon in detail by collecting data through conducting an investigation on the case being studied (Salim \& Syahrum, 2012). Meanwhile, descriptive analysis technique is a method used to analyze data by describing and portraying the data that was collected (Sugiyono, 2013).

Data collection was carried out through case study approach by collecting primary and secondary data. Primary data was obtained through interview with several involved 
parties that includes the principal of the school, the international cooperation program coordinator, as well as several student and teacher representatives who participated in MA Daarul Uluum PUI Majalengka's exchange program. Meanwhile, the secondary data was obtained through literature study of books, journals, reports, other written sources to support the study.

\section{RESULTS AND DISCUSSION}

\subsection{Dynamic of the Southern Thailand Identity Conflict Efforts to Resolve the Conflict}

The ongoing conflict in the Southern Thailand region has similar problematics to those mentioned by (Coser, 1964) if a conflict is used to uphold or preserve a community's identity through religious, ethnical, and belief issues within a plural society. That is also the case of the Southern Thailand conflict where there occurs identity rivalry between the minority Muslim community who are trying to preserve their religious and cultural values during the cultural assimilation policy (Ekawati, 2019; Wayeekao, 2016).

Several forms of the cultural assimilation policy were implemented through banning the use of Malay Muslim names, language, and identity in social life. In order to be accepted in public schools and work in government institutions, the Malay Muslim community were pressured to disregard their Malay or Moslem identity. That is considered a form of discrimination against the Malay Muslim community, as they are being forced to disregard their identities and done identities that are Thai and Buddhist (Kusuma, 2016; Sanurdi, 2018).

The long streak of conflict that occurred since the implementation of indirect cultural uniformity objectives resulted in the failure to fulfill human rights since the Malay Muslim community lost their freedom of identity (Jehma et al., 2017). The loss of their freedom led to the presence of several protest movements that demanded fulfillment of autonomic rights for the Southern Thailand Malay Muslim caused by factors of poverty and social inequality (Engvall \& Andersson, 2014). The movements were also triggered by the obsolete democratic relations between the central Thai government and the Southern Thailand regional government (Mania, 2019; Yuniarto, 2005). This was further strengthened by there being primordialist principles (Nurakkate, 2012) and strong influence from Islamic 
principles stemming from the Malay Muslim community themselves (Melvin, 2007; Möller, 2011). However, the emergence of these protest movements have led to the growing of fear and suspicion towards Muslims or "Islamophobia" in the Thailand society, where they perceive the Malay Muslims as a group of criminals behind their religious attire (Engvall \& Andersson, 2014; Fahmi, 2016).

The appearance of implications of such suspicion between religion or beliefs in society proves that the ongoing conflict cannot be separated from the use of the label "conflict between religions" (Jory, 2007). This fact can be seen from the government's attempts to erase the Malay term in the Southern Thailand people and replace it with the term "Thai Muslim", with the reasoning to prevent the secession of Malay Moslem people from the Thai government through identity background (Kusuma, 2016). Consequently, this ongoing conflict between the two parties is categorized as an ethno-religion conflict of the Malay Muslim and Thai Buddhist ethnic identity.

However, religious identity conflict is often ignited by extremist people that act harshly and exaggeratedly compared to the moderate people within their community who implement inclusive tolerant values (Yusuf, 2017). Therefore, it is necessary to note that not all elements of the Thai society participate in this discrimination or are involved in the conflict with the Malay-Muslims. Hence, an effective resolution is needed due to the complexity of this long-term conflict in Southern Thailand.

\subsection{Efforts to Resolve the Conflict}

Along with the development of international relations activities, the role of the state and other international relations actors are charged with having to provide space and facilitate each actor involved in efforts of world peace, one of which is the movements of non-state actors that have potential and flexibility to be involved in peacebuilding efforts (Galtung, 1996; Miall et al., 2005). Thus, their presence can produce innovations and new ideas in the practice of international cooperation. Noted, this creation of space for non-state actors to involve themselves in peacebuilding efforts is one form of integration between various sector and global international relations actor to be engaged in each other's attempts to create world peace. As what is being carried out by MA Daarul Uluum PUI Majalengka as one 
BERUIMPUIN

International Journal of Social, Politics, and Humanities

https://berumpun.ubb.ac.id/index.php/BRP

of the Islamic senior high schools in Indonesia, wherein its role is categorized as a non-state actor that focuses on education development, who participates in promoting how to resolve the conflict in the southern Thailand region by involving themselves in peacebuilding efforts through multiculturalism education.

MA Daarul Uluum PUI Majalengka have provided a viewpoint where newer steps and strategies of peacebuilding efforts are necessary in facing the Southern Thailand conflict. Based on the dynamics and complexity of the situation in Southern Thailand, MA Daarul Uluum PUI Majalengka perceives education to be one of the sectors that can be made into an alternative through cooperation by several education institutions between states in the international community, in order to promote peacebuilding efforts through the education sector (A. Ridwan, Headmaster, May 2, 2021).

The teacher and student exchange program like what is held by MA Daarul Uluum PUI Majalengka with several schools in Thailand (see Table 2), is a form of strategic approach through education collaboration in promoting conflict transformation in Southern Thailand. One of the aims of this teacher and student exchange program is to campaign the spirit of harmony in the midst of differences where MA Daarul Uluum PUI Majalengka are working together with schools in Thailand in a student exchange program that sends Moslem students to live and study in Buddhist schools, and vice versa.

During the earlier period of the program, MA Daarul Uluum focused on cooperating with several schools located outside the region of conflict or outside Southern Thailand. This was the target and plan of MA Daarul Uluum to build and promote a better image of an Islamic group in the midst of Islamophobia stigmatization that once occurred. By doing so, they could plant the spirit of peace in the Buddhist community around Thailand. This was made into a momentum to carry out conflict transformation to change identity differences that were seen as negative into being more positive, as it the aim of conflict transformation itself. This indicates that there being differences in identity will not become an issue despite the ongoing identity conflict in Southern Thailand, since a plural society must be able to appreciate the exchange of culture and unity at all levels in order to create a condition where 
no individual or group feels trapped, threatened, or isolated by the greater society (Parekh, 2008).

This cooperation was carried out in massive and received good responses from each party as the program took place, from the year 2018 until the end of 2019, though for the next few years the teacher and student exchange program had to be temporarily halted due to complications from COVID-19. The following are the data of the program implementation that took place from the beginning period:

Table 2. MA Daarul Uluum PUI Majalengka to Thailand Schools

\begin{tabular}{|c|c|c|c|c|}
\hline Session & Period of Exchange & Student & Teacher & Host Institution \\
\hline 1 & $\begin{array}{c}\text { January } 25 \text {-February 18, } \\
2018\end{array}$ & 4 & - & $\begin{array}{l}\text { Lopbury College of Agriculture and } \\
\text { Technology } \\
\text { Petchabun College of Agriculture and } \\
\text { Technology }\end{array}$ \\
\hline 2 & $\begin{array}{l}\text { June } 23 \text { - July 20, } 2018 \\
\qquad \& \\
\text { July } 20 \text { - August } 16,2018\end{array}$ & - & 2 & $\begin{array}{l}\text { Lopbury College of Agriculture and } \\
\text { Technology }\end{array}$ \\
\hline 3 & $\begin{array}{c}\text { November } 8 \text {-December } 2 \text {, } \\
2018\end{array}$ & 2 & - & $\begin{array}{l}\text { Lopburi Vocational College } \\
\text { Nakronswan College of Agriculture and } \\
\text { Technology }\end{array}$ \\
\hline 4 & $\begin{array}{c}\text { October } 30 \text { - November 23, } \\
2019\end{array}$ & 3 & 1 & $\begin{array}{l}\text { Lopbury College of Agriculture and } \\
\text { Technology }\end{array}$ \\
\hline
\end{tabular}

Source: Archive of MA Daarul Uluum PUI Majalengka International Cooperation Program Department 
BERUIMPUIN

International Journal of Social, Politics, and Humanities

https://berumpun.ubb.ac.id/index.php/BRP

Table 3. Thailand Schools to MA Daarul Uluum PUI Majalengka

\begin{tabular}{ccccl}
\hline Session & Period of Exchange & Student & Teacher & Home Institution \\
\hline \multirow{3}{*}{1} & March 13- April 10, & 3 & - & $\begin{array}{l}\text { Lopbury College of Agriculture and } \\
\text { Technology }\end{array}$ \\
& 2018 & 2 & 1 & Lopburi Vocational College \\
& & & & \\
\hline
\end{tabular}

Source: Archive of MA Daarul Uluum PUI Majalengka International Cooperation Program Department

It can be seen that the student and teacher exchange program conducted several times each year was made as an attempt to maximize the relation pattern between both parties as non-state actors with a peace mission through education cooperation program. From the massiveness of the frequency of the exchange, MA Daarul Uluum PUI Majalengka perceived its strategy to promote peace in Southern Thailand was accomplished. In their practice, MA Daarul Uluum emphasized a strategy that includes the four aspects of conflict transformation according to (Lederach, 2003), by emphasizing conflict source management as a process of realizing long term peace (Bercovitch, 1996), as follows:

\subsubsection{Personal Transformation}

This aspect aims to release an individual from the deconstructive effects caused by social conflict that could come in the form of physical as well as mental wounds that change the individuals emotional, perceptive, and spiritual aspects. The growth of Islamophobia in Thailand indirectly had constructed negative view within the Thai community of the large scale rebellion from the resistance movement fighting for the freedom of Malay Muslim who label themselves as "Muslim" movements. In this case study, the practice of the MA Daarul Uluum student and teacher exchange allowed them to live in close quarters with Thai society, which is an initial step to building and maintaining holistic relations in order to minimalize stigmatism of Islamophobia in an environment that perceives a group of Muslims to be a group of violent people or terrorist. This program is also in line with one of the aims of conflict resolution education that leads to peacemaking through emotional management towards parties involved or affected by the conflict.

Through direct interaction patterns throughout the period of the student exchange program, which lasted 1 month each period, the activities allowed an intense pattern of 
relations and communications between two different identities (Muslim and Buddhist). Those relation and communication interactions took place through inclusive dialogues where the parties introduced and learned each other's identities. This occurred from both parties, the MA Daarul Uluum students with their Muslim backgrounds, and also the Thai community with their Buddhist background. The continuity of these interaction patterns that built ties between both parties were not limited to these mere dialogues of discussion and sharing of knowledge. It extended to practice of religious and cultural activities on a daily basis which was done by MA Daarul Uluum in representing Islam positively, which indirectly also built a positive image of Islam and cured the wounds of the Thai community inflicted by past Malay Muslim resistance movements.

This applies viceversa, throughout the student exchange program, Thai students that visited Indonesia also lived closely and followed the learning process in the midst of Muslim majority people of Indonesia. This was done as means to develop good communication and interaction patterns between two groups of different identity backgrounds. Therefore, as the Thai students witness the Muslim community that welcomes their presence, this indirectly turns the long existing negative stigmatization into a positive perception of Islam. Due to this, freeing the individuals from the deconstructive effects of conflict was possible. This result can also be found in the transformation approach strategy through the relational aspect.

\subsubsection{Relational Transformation}

For this aspect, attempts to recover communication patterns through building interaction relations is one of the focus of relational transformation. Such as the efforts of MA Daarul Uluum in transforming the effect of Islamophobia stigmatization that is also included in the personal transformation strategy of conflict resolution. It must be noted that the effects of Islamophobia that constructs the perception and mindset of society also affected the pattern and relation of interaction in society.

Through activity approaches such as dialogue, living in close quarters behind each routine activities of both parties become a part of the transformation process at a personal level. This indirectly brings values of relational transformation approach by recovering the 
interaction relation pattern into a more harmonious direction through understanding differences in identity. This is because, in the efforts to build peace between different identities, a holistic relationship is necessary in order to understand one another and accept differences between identities (Mbachaga, 2012).

In the context of this study, the student and teacher exchange program also endeavored to form a community that acts as a student forum of communication which can unite all the students despite their identity differences. Hence, this communication forum can become a medium to develop communication patterns for a long term between both parties with the aim to maintain the stability of peace. As this interaction relation was formed, both identity groups also facilitated the needs to support their activities, from providing a place for worship to selecting halal food for Moslems. These details indicate that multiculturalism values have strengthened, and supports the argument that differences is not a source of conflict. According to (Wallace, 1970), despite there being identity differences in a group, if the activities implement principles of openness and understanding towards one another, then that community can be more organized in facilitating equal interaction patterns.

Stemming from that fact, the approach chosen by MA Daarul Uluum in the relational transformation aspect emphasizes more on human rights education approach whose aim is to build respect towards human values such as accepting different identity backgrounds. In their practice, MA Daarul Uluum indirectly has elaborated the values of both personal transformation and relational transformation efforts to minimize the spreading of negative stigma by building a positive pattern of interaction relation.

\subsubsection{Structural transformation}

Promoting peace through building and managing social, economic and institutional relations as an effort to fulfill rights and basic human needs is a part of the conflict transformation concept carried out through structural transformation approach. In this case, the fulfillment of basic human needs that is already part of their rights is the focus of the structural transformation approach, wherein the institution is one of the instruments in the process. Education is one of the institutional sectors that is a concern of MA Daarul Uluum in their 
role to promote peace in Thailand. Since the implementation of the culture assimilation policy in southern Thailand also effects the identity uniformity in the education which violates multiculturalism values as their basic human needs that indirectly discriminates the Malay Moslem people and prompts conflict to occur (Aslan et al., 2020). In order to address those issues, MA Daarul Uluum sees the exchange program as capable of promoting peace and fulfilling human rights for all elements of society, with no discrimination towards a specific identity group, as a form of the goal to implement human rights education.

In the process, the implementation of structural transformation approach that focuses on the education sector is carried out by MA Daarul Uluum through both formal and non-formal learning activities. Formal activities were applied on the teacher exchange program, where the intended focus was to teach subjects such as English as an international language in the classroom of several Thai schools that participated in the program. Meanwhile, the non-formal learning approach is the interaction between students. This is the main media through activities of cultural exchange such as practicing art, learning the language of each party, to sharing basic religious teachings as knowledge or religious teachings that are indirectly taken from each religion's day-to-day practices (I.Hasanah, MA Daarul Uluum student, May 20, 2021).

In addition, other activities targeted to enhance the student's soft skills in the field of agricultural technology is an additional course, taking into account that both Thailand and Indonesia are agriculture states. From these activities, it can be inferred those differences of identity in an education institution is not an issue that hinders the conduciveness of the learning process. Therefore, an education institution is charged with not discriminating a specific identity group, as part of the fulfillment of basic human rights. Thus, through the institutional transformation aspect approach wherein students and teacher are sent to schools in Thailand regions dominated by Buddhist citizens, MA Daarul Uluum assesses the program is capable of influencing how Muslims can still maintain their identities during institutional activity settings. 


\subsubsection{Cultural Transformation}

Efforts of sustainable conflict resolution which has given adequate impact or implications to community social relations is no doubt a challenge to actors who play a role in peacemaking. Through the cultural transformation approach, MA Daarul Uluum perceives the planting of multiculturalism values as one method that can be achieved through education in order to minimalize conflict, since the cultural assimilation policy was the starting point that triggered conflict between the Malay-Muslims and the Thai government. In this case, the process of applying the cultural transformation concept aims to identify and understand cultural pattern that cause conflict, then address that conflict through constructive cultural management and development which is the aim of the practice of conflict resolution education, wherein the aim of constructive cultural development is to realize culture as a value to be respected. Due to this matter MA Daarul Uluum aimed to plant multiculturalism values as a part of their effort to realize culture as a form to be respected in conflict resolution.

During the process, the approach through the concept of cultural transformation carried by the students and teacher of the exchange program were done in the form of visitation activities in both Thailand and Indonesia to historic landmarks that represent the identity of each party. These activities aimed to yield a deeper insight to the parties' cultural as well as religious values. Through this positive exchange of historical knowledge, the values of multiculturalism are also implanted into the students in which they learn how to appreciate each other's identity differences.

\section{CONCLUSION}

In conclusion, as the activities of international relations continues to develop, non-state actors now have a greater space and important role to play with their potential and ability to participate in various international relations agenda. MA Daarul Ulum PUI Majalengka is one of the education institutions in Indonesia who plays a role in international cooperation within the education sector and has proven how non-state actors can also be active in their role by focusing on specific approaches, especially in promoting world peace, which is a vision that remains hindered by several challenges. 
By utilizing all four aspects of conflict transformation (personal transformation, relational transformation, structural transformation, and cultural transformation) through peace education approach, MA Daarul Ulum PUI Majalengka has described that peacebuilding efforts can be done using nonviolence methods (positive peace). This strategy was applied by focusing on building multiculturalism values that were applied within the student and teacher exchange program as an effort of conflict transformation in the conflict region of Southern Thailand, which is seen as a form of challenge to realize global peace. Keeping in mind that the dynamics and effect of ethno-religion conflict that is occurring in Southern Thailand indicates that basic human rights remain unfulfilled and the absence of principle of mutual respect regarding differences in identities as is part of the concept of multiculturalism to realize world peace.

\section{REFERENCES}

Alunaza SD, H., \& Amijoyo, R. R. S. (2019). Kebijakan luar negeri najib razak terhadap konsolidasi thailand dan gerakan aliansi separatisme etnis melayu di thailand selatan di tahun 2013 - 2016. Mandala Jurnal Hubungan Internasional, 2(1), 96-114. https://doi.org/http://dx.doi.org/10.33822/jm.v2i1.997

Ashayagachat, A. (2016). OIC ready to assist on unrest in deep South. Bangkok Post. https://www.bangkokpost.com/thailand/politics/825428/oic-ready-to-assist-onunrest-in-deep-south (May 29, 2021)

Aslan, Hifza, \& Suhardi, M. (2020). Dinamika Pendidikan Islam Di Thailand Pada Abad 19-20. Nazhruna: Jurnal Pendidikan Islam, 3(1), 38-54. https://doi.org/10.31538/nzh.v3i1.476

Bercovitch, J. (1996). Resolving international conflicts : the theory and practice of mediation. Boulder, Colorado: Lynne Rienner Publishers.

Coser, L. A. (1964). The functions of social conflict. New York: Free Press.

Dudouet, V. (2006). Transitions from Violence to Peace. Berlin: Berghof Research Center for Constructive Conflict Management. 
BERUIMPUIN

International Journal of Social, Politics, and Humanities

https://berumpun.ubb.ac.id/index.php/BRP

Ekawati, D. (2019). Migrasi dan Problematika Minoritas Muslim Thailand. Hikmah Journal of Islamic Studies, 15(1), 51-79. https://doi.org/10.47466/hikmah.v15i1.125

Engvall, A., \& Andersson, M. (2014). The Dynamics of Conflict in Southern Thailand. Asian Economic Papers, 13(3), 1-21. https://doi.org/10.1162/ASEP_a_00303

Fahmi, M. (2016). Radikalisme Islam dalam Representasi Media di Thailand. Al-Ulum Journal IAIN Gorontalo, 16(2), 1-23. https://doi.org/https://doi.org/10.30603/au.v16i2.159

Fathurachmi, E. (2014). Intractable Conflict in Southern Thailand. INSIGNIA Journal of International Relations, 1(01), 10. https://doi.org/https://doi.org/10.20884/1.ins.2014.1.01.414

Fountain, S. (1999). Peace Education in UNICEF. New York.

Galtung, J. (1996). Peace by Peaceful Means: Peace and Conflict, Developmentand Civilization (1st ed.). Oslo, London: International Peace Research Institute, SAGE Publication.

Harris, I. M. (2007). Peace education theory. Journal of Peace Education, 1(1), 5-20. https://doi.org/10.1080/1740020032000178276

Jehma, R., Sumardi, \& Sugiyanto. (2017). The Nationalism movement of Islam for Independence of Patani Southern Thailand (1902-1945). Jurnal Historica, 1(1), 1-14.

Jory, P. (2007). From Melayu Patani to Thai Muslim the Spectre of Ethnic Identity in Southern Thailand. South East Asia Research, 15(2), 255-279. https://www.jstor.org/stable/23750846

Kristimanta, P. A. (2020). Tren dan Pemicu Kekerasan Teorganisasi di Asia Tenggara 19892018. Jurnal Penelitian Politik, 17(1), 79-102. http://ejournal.politik.lipi.go.id/index.php/jpp/article/view/851

Kusuma, B. M. A. (2016). Masyarakat Muslim Thailand dan Dampak Psikologis Kebijakan Asimilasi Budaya. Hisbah: Jurnal Bimbingan Konseling Dan Dakwah Islam, 13(1), 109120. http://ejournal.uin-suka.ac.id/dakwah/hisbah/article/view/1006 
Kusuma, B. M. A. (2017). Islam Asymmetric Policy, and Social Conflict: The State 's Role as a Root of Radicalism in the Philippines and Thailand. The Indonesian Journal of Southeast Asian Studies, 1(1), 33-46.

Kymlicka, W. (2003). Kewargaan Multikultural (E. H. Eddin (ed.); Pertama). Jakarta: PT Pustaka LP3ES Indonesia.

Latief, H., \& Nashir, H. (2020). Local Dynamics and Global Engagements of the Islamic Modernist Movement in Contemporary Indonesia: The Case of Muhammadiyah (20002020). Journal of Current Southeast Asian Affairs, 39(2), 290-309. https://doi.org/10.1177/1868103420910514

Lederach, J. P. (1997). Building Peace Sustainable: Reconciliation in Divided Societies-United States Institute of Peace (1st ed.). Washington DC: United States Institute of Peace.

Lederach, J. P. (2003). The Little Book of Conflict Transformation (D. J. Ranck (ed.); 1st ed.). New York: Good Books.

Liwe, A. J. (2018). Makna strategis kajian wilayah asia tenggara dari sudut pandang hubungan internasional. Jurnal VERITY: Hubungan Internasional, 10(20), 87-95. https://ojs.uph.edu/index.php/JHIV/article/view/1460

Ludfiani, A., Hara, A. E., \& Sunarko, S. (2017). Krisis Kemanusiaan dan Upaya Thailand Mengatasi Gelombang Pengungsi Rohingya (Humanitarian Crisis and Thailand 's Effort in Overcoming the Wave of Rohingya Refugees ). E-Sospol, IV, 82-88.

Maharani, Z. D. (2018). Peran Malaysia dalam Penyelesaian Konflik Thailand Selatan 2005 2013. Jakarta. Retrieved from https://repository.uinjkt.ac.id/dspace/bitstream/123456789/44932/1/Zhuhrufa Dita Maharani_Fix.pdf

Mania. (2019). Perkembangan Sosial Islam di Thailand. Al Ma' Arief: Jurnal Pendidikan Sosial Dan Budaya, 1(1), 1-11. 
BERUIMPUIN

International Journal of Social, Politics, and Humanities

https://berumpun.ubb.ac.id/index.php/BRP

Margono. (2015). Aktor Non-Negara Dalam Hubungan Internasional. Jurnal Pendidikan Pancasila Dan Kewarganegaraan,28(2), 105-110.

Mbachaga, J. D. (2012). Managing Diversity; Promoting Nation Building and Peace in Nigeria: a Critical Reading of Sunnie Ododo's Hard Choice. A Gazelle of the Savannah, 1, 125 133.

Melvin, N. (2007). Conflict in Souther Thailand: Islamism, Violence, and the State in the Patani Insurgency. SIPRI Policy Paper, 1-40.

Miall, H. (2004). Conflict Transformation: A Multi-Dimensional Task. In Transforming Ethnopolitical Conflict (pp. 67-89). Wiesbaden: Springer Fachmedien Wiesbaden. https://doi.org/10.1007/978-3-663-05642-3_4

Miall, H., Ramsbotham, O., \& Woodhouse, T. (2005). Contemporary Conflict Resolution (2nd ed.). Cambridge: Polity Press.

Möller, T. M. (2011). Insurgency in Southern Thailand: A Quest for Identity. Security and Peace, 29(1), 1-7.

Nuereng, I. (2016). Dinamika bernegara masyarakat muslim Thailand selatan dalam perspektif sosiologi politik Islam. Jurnal Agama Dan Hak Azazi Manusia, 5(2), 298-351.

Nurakkate, C. (2012). The Conflict in Southern Thailand. In Center for Defence and Strategic Studies. Australian Defence College.

Parekh, B. (2008). Rethingking Multiculturalism Keberagaman Budaya dan Teori Politik (B. K. Adi (ed.); 2nd ed.). Yogyakarta: Penerbit Kanisius.

Raharjo, S. N. I. (2015). Peran Identitas Agama Dalam Konflik di Rakhine Myanmar Tahun 2012 - 2013. Jurnal Kajian Wilayah, 6(1), 35-51.

Rinayuhani, T. R. (2014). Asean dalam Persepsi Ancaman. Fakultas Ilmu Sosial Dan Ilmu Politik Universitas Islam Majapahit, 7(2), 46-52. http://www.unim.ac.id/jurnal-orasivolume-7-no-2-tahun-2014/ 
BERUMPUIN

International Journal of Social, Politics, and Humanities

https://berumpun.ubb.ac.id/index.php/BRP

Salim, \& Syahrum. (2012). Metode Penelitian Kualitatif (Haidir (ed.)). Bandung: Citapustaka Media.

Sanurdi, S. (2018). Islam di Thailand. Tasamuh: Jurnal Studi Islam, 10(2). https://doi.org/10.32489/tasamuh.42

Sharqieh, I. (2012). Peace and Conflict Studies Can the Organization of Islamic Cooperation (OIC) Resolve Conflicts? Peace and Conflict Studies, 19(2), 219-236.

Sholeh, B. (2017). Resolusi Konflik Di Asia Tenggara: Pengalaman Muslim Indonesia. Epistemé: Jurnal Pengembangan Ilmu Keislaman, 12(1), 29-52. https://doi.org/10.21274/epis. 2017.12.1.29-52

Sobandi, K. R. (2011). Separatisme di Asia Tenggara: Antara Penguasa dan Gerakan Nasionalis Kelompok Minoritas. Jurnal Kajian Wilayah, 2(1), 35-55. http://jkw.psdr.lipi.go.id/ind ex.php/jkw/article/view/320

Sugito, Warsito, T., Nurmandi, A., \& Qodir, Z. (2020). Will informal institutions replace formal institutions? The primacy of church and "uma lisan" in fostering community security in timor leste. Revista UNISCI,2020(53), 77-94. https://doi.org/10.31439/UNISCI-84

Sugiyono. (2013). Metode Penelitian Pendidikan Pendekatan Kuantitatif, Kualitatif, dan R\&D. Bandung: Alfabeta.

Syafe'i, Mahendrawati, N., \& Ahmad. (2001). Pengembangan Masyarakat Islam: Dari Ideologi, Sosiologi, sampai Tradisi. Bandung: Remaha Rosda Karya.

United Nations, Department of Economic and Social Affairs, P. D. (2020). thailand population (live). World Population. https://www.worldometers.info/world-population/thailandpopulation/ (May, 27 2021)

Wallace, A. F. C. (1970). Culture and Personality (2nd editio). New York: Random House.

Wayeekao, N. (2016). Berislam dan Bernegara bagi Muslim Patani: Perspektif Politik Profetik. IN RIGHT, 5(2), 1-55. 
Yuniarto, P. R. (2005). Minoritas Muslim di Thailand: Asimilasi, Perlawanan Budaya dan Akar Gerakan Separatisme. Jurnal Masyarakat Dan Budaya, 7(1).

Yusuf, I. (2017). Celebrating Muhammad's Birthday in Buddha's Land and Managing Religious Relations Through Religious Festival. In D. Sofjan (Ed.), Religion, Public Policy and Social Transformation in Southeast Asia: Religion, Gender and Identity (2nd ed., p. 127). Geneva: Globethics.net.

Zahidi, M. S. (2015). Double Standard Indonesia Dalam Diplomasi Kemanusiaan. INSIGNIA $\begin{array}{llll}\text { Journal of International } & \text { Relations, } & \text { 2(1), }\end{array}$ https://doi.org/10.20884/1.ins.2015.2.01.451 